\title{
Non-lethal detection of DNA from Cichlidogyrus spp. (Monogenea, Ancyrocephalinae) in gill mucus of the Nile tilapia Oreochromis niloticus
}

\author{
Juan Pablo Ek-Huchim ${ }^{1}$, Isabel Jimenez-Garcia ${ }^{2}$, Juan Antonio Pérez-Vega ${ }^{1}$, \\ Rossanna Rodríguez-Canul ${ }^{1, *}$
}

\author{
${ }^{1}$ Laboratorio de Inmunología y Biología Molecular, \\ Centro de Investigación y de Estudios Avanzados del Instituto Politécnico Nacional-Unidad Mérida, Km 6 Antigua Carretera \\ a Progreso, CORDEMEX, Mérida, Yucatán, 97310 México \\ ${ }^{2}$ Instituto Tecnológico de Boca del Rio, Km 12 Carretera Veracruz-Córdoba, Boca del Río, Veracruz, C.P. 94290 México
}

\begin{abstract}
Infection of Nile tilapia Oreochromis niloticus by monogeneans of the genus Cichlidogyrus is harmful. Currently, diagnosis of this infection is based on invasive techniques and the identification of isolated parasites by their morphology. To facilitate diagnosis, we have developed a non-lethal polymerase chain reaction (PCR) test for detection of Cichlidogyrus spp. DNA in the gill mucus of $O$. niloticus, using 5 pairs of specific primers based on Cichlidogyrus sclerosus $28 \mathrm{~S}$ rRNA (Cicly 1 to Cicly 5) which generate fragments of approximately 188, 180, 150, 159 and $189 \mathrm{bp}$, respectively. PCR specificity was tested using genomic DNA extracted individually from 175 isolated Cichlidogyrus spp., 75 Gyrodactylus cichlidarum and 75 endopararasitic Enterogyrus spp., as well as from 75 protozoans Trichodina spp. The Cicly primers were used to detect Cichlidogyrus spp. DNA in mucus from the gills of 23 Nile tilapia confirmed to be infected with the parasite. Negative controls consisted of 45 uninfected Nile tilapia. The limit of sensitivity of the assay was $1.2 \mathrm{ng}$ of purified parasite DNA. The Cicly primers did not amplify DNA from the mucus of non-infected Nile tilapia, G. cichlidarum, Trichodina spp. or Enterogyrus spp. In all cases, the sensitivity and specificity of the test were $100 \%$. The sequences of all the amplified fragments showed a high similarity to that of the 28S rRNA region of C. sclerosus (93 to $100 \%$ identical to GenBank Accession No. DQ157660.1). We provide evidence for a safe and noninvasive DNA-based diagnostic method for the presence of Cichlidogyrus in the gill mucus of O. niloticus.
\end{abstract}

KEY WORDS: Diagnosis $\cdot$ Ectoparasite $\cdot$ Monogenean $\cdot$ PCR

Resale or republication not permitted without written consent of the publisher

\section{INTRODUCTION}

Nile tilapia Oreochromis niloticus has a high economic demand around the world, making it attractive for culture (Fitzsimmons \& Carvalho 2000). It grows rapidly, is highly adaptable to water conditions, and is very tolerant to stress caused by handling (ElSayed 2006). Over 2 million tonnes of the fish are estimated to be produced annually worldwide (Gonçalves et al. 2009). Monogeneans of the genus Cichlidogyrus (order Monophisthocotylea) are among the major parasites of Nile tilapia, causing cichlidogyriasis. These ectoparasites attach themselves to their hosts' gills by a structure called a haptor located in the posterior region of the body; the haptor is armed with hooks and bars but does not 
have discrete multiple suckers and clamps. These monogeneans feed on mucus, skin cells and blood from their site of attachment in the gill lamellae, using an anterior oral sucker (Gonçalves et al. 2009). Histological sections of gill tissue from severe monogenean infestations show excessive mucus production and hyperplasia that could lead to fusion of gill lamellae. Lesions in the gills could be fatal, especially under poor environmental conditions such as low oxygen content (Kabata 1985). In natural environments, Cichlidogyrus spp. are commonly found in apparent equilibrium with their host fish; in freeranging populations it is not easy to determine whether monogeneans are the direct cause of mortality in Nile tilapia. However, the situation can be very different in cultured Nile tilapia. Because of their direct life cycle, these parasites can proliferate very quickly in environments with high densities of fish, such as tanks or ponds with inadequate sanitation and poor water quality; the parasites may thus be transmitted readily from fish to fish, resulting in epidemic levels of morbidity and mortality (Buchmann \& Lindenstrom 2002). Cichlidogyrus sclerosus has been reported as the cause of death in cultured Oreochromis spp. introduced to Southeast Asia (Khalil 1971). A few monogeneans on a healthy, mature fish are usually not significant; however, moderate numbers on young fish can cause significant mortalities (Kabata 1985).

Clinical signs of cichlidogyriasis are not easily noticed in the early stages of infection. Fishes may become lethargic, and swim near the surface or seek the bottom of the tank, but in heavy parasitic infestations the gills may be swollen and pale, the respiration rate may be increased, and the fish will be less tolerant of low levels of oxygen; fishes with severe respiratory distress may be observed (R. RodríguezCanul pers. obs.). Secondary infection by bacteria and fungus is common in tissues that have been damaged by monogeneans (Wu et al. 2006).

Currently, the identification of monogeneans is carried out, post-mortem, by examination of fish gills; identification is based on an analysis of the parasite's morphology and on the size of sclerotized parts of the haptor and the reproductive organs (Paperna \& Thurston 1968, Smith et al. 1992). Even though parasitology is considered to be the 'gold standard' test, this technique is lethal for the fish and it depends on the experience of a well-trained technician. Serological tests based on enzymelinked immunosorbent assay (ELISA) identify IgM antibodies specific for Cichlidogyrus spp. (Sandoval-Gío et al. 2008). A major limitation of both of these techniques is that they are invasive to the host. Moreover, the presumptive diagnosis of cichlidogyriasis in a given farm implies additional costs for definitive diagnosis, management and treatment. Currently, several assays have been developed for the detection of pathogens in other species of fish using non-lethal sampling methods (Miriam et al. 1997, López-Vázquez et al. 2006, Lindstrom et al. 2009, Sanders \& Kent 2011).

A non-invasive test that could detect pre-patent or low levels of monogenean infection would be useful. In this study, we describe a test based on the identification of genomic DNA from Cichlidogyrus sp. in the gill mucus of Nile tilapia; the test is novel, safe, and non-invasive to the fish, and it can be useful for presumptive diagnosis of cichlidogyriasis.

\section{MATERIALS AND METHODS}

\section{Biological material}

Cichlidogyrus spp. (175 individuals) were isolated from the gills of naturally infected Nile tilapia from the CINVESTAV - IPN Unidad Mérida facilities and stored individually in Eppendorf tubes with $70 \%$ ethanol. Briefly, Nile tilapia were sacrificed by inserting a knife behind the eyes and towards the upper edge of the operculum, piercing the brain; this procedure was performed very quickly, resulting in instant death. Gills were then removed and placed individually in Petri dishes containing $0.7 \%$ saline solution. Parasites were counted and isolated at $10 \times$, and morphological features were observed at $40 \times$ and $100 \times$.

The heterologous group included 75 individuals of Gyrodactilus cichlidarum (Paperna 1968), 75 protozoans (Trichodina spp.) and 75 individuals of Enterogyrus spp.; these organisms were isolated from the stomach of Nile tilapia.

\section{Isolation of mucus from the gills of Nile tilapia and extraction of DNA}

Mucus from 23 Nile tilapia, known to be infected with Cichlidogyrus spp., was collected by swabbing. Briefly, a Nile tilapia was placed on a clean surface, and 1 technician restrained it firmly with his hand while another technician handled a sterile dry cotton swab. The swab was placed gently inside the operculum and rotated gently for $5 \mathrm{~s}$ on the external surface of the left and right sides of the fish gills, avoiding causing excessive tissue damage. The swab was then 
gently removed from the gills and placed in a sterile $0.5 \mathrm{ml}$ Eppendorf tube with a hole in the bottom. This tube was placed on a collector tube of $1.5 \mathrm{ml}$ and centrifuged at $13500 \times g$. About 40 to $50 \mu \mathrm{l}$ of mucus was collected. This was separated, in equal volumes, into 2 tubes for extraction of DNA. The contents of 1 tube was fixed in ethanol $(96 \%)$ and the contents of the other tube was immediately used for extracting DNA using the Wizard $^{\circledR}$ genomic DNA purification kit (Promega ${ }^{\circledR}$ ) according to the manufacturer's protocol. To assess the worm burden, fishes were then dissected and gills removed for isolation of the parasites at $10 \times$ and 40× (Jiménez-García et al. 2001).

For negative controls, mucus was collected from 45 uninfected Nile tilapia and used for the extraction of DNA, as described above for the positive control group.

\section{Extraction of parasitic genomic DNA and design of primers}

Genomic DNA was isolated by a modification of the method described by Mollaret et al. (2000). DNA was extracted from single specimens placed individually in Eppendorf tubes incubated at $55^{\circ} \mathrm{C}$ for $2 \mathrm{~h}$ with a mixture of $10 \mu \mathrm{l}$ of Proteinase K $\left(20 \mu \mathrm{g} \mathrm{ml}^{-1}\right)$ (Sigma) and $150 \mu \mathrm{l}$ of $10 \%$ Chelex (Sigma).

The concentration of DNA was determined using a NanoDrop 2000c spectrophotometer (Thermo Scientific) by measuring absorbance values at $260 \mathrm{~nm}$ and $280 \mathrm{~nm}$, and determining the ratio $\mathrm{A}_{260} / \mathrm{A}_{280}$. Samples with a value of $\sim 1.8$ and above were used in the subsequent polymerase chain reaction (PCR) assays.

Primers were synthesized on the basis of the region D1 to D2 of the large subunit (LSU) 28S rDNA gene of Cichlidogyrus sclerosus (DQ157660.1) (Wu et al. 2006) with the aid of the primer3 (v.0.40) software program (Rozen \& Skaletsky 2000). The following criteria were applied to the design of the new primers: GC content from 45 to $60 \%$; minimal secondary structure; no primer-dimers; melting temperature $\left(T_{\mathrm{m}}\right)$ between 50 and $70^{\circ} \mathrm{C}_{i}$ and a length of 20 to 24 bases. Details of the primers are shown in Table 1.

In all cases, 15 serial dilutions of each primer (100 pM to $1 \mathrm{pM}$ ) and 15 serial dilutions of the DNA (from 64 to $0.0039 \mathrm{ng}$ ) were performed to assess the limitation of the PCR assays.

The sensitivity and specificity of each PCR was evaluated by $\chi^{2}(2 \times 2)$ (Galen \& Gambino 1995).

\section{PCR assays}

The PCR reactions were carried out in a total volume of $20 \mu \mathrm{l}$ containing $2 \mu \mathrm{l}$ of template $(\sim 32.5 \mathrm{ng}$ of DNA of single parasites), $0.30 \mu \mathrm{M}$ of each primer, $1.5 \mathrm{mM}$ of $\mathrm{MgCl}_{2}, 10 \times$ reaction buffer $(50 \mathrm{mM} \mathrm{KCl}$, $10 \mathrm{mM}$ Tris- $\mathrm{HCl}, 0.1 \%$ Triton X-100, $\mathrm{pH} 9.0), 0.3 \mathrm{mM}$ dNTPs mixture (Promega ${ }^{\circledR}$ ) and $3.0 \mathrm{U}$ of Taq DNA polymerase (BioLabs ${ }^{\circledR}$ ). The PCR reactions were run on a thermal cycler (TECHNE TC-312) and the cycling conditions were $95^{\circ} \mathrm{C}$ for $3 \mathrm{~min}$, followed by 35 cycles of $94^{\circ} \mathrm{C}$ for $1 \mathrm{~min}, 50^{\circ} \mathrm{C}$ for $1 \mathrm{~min}$, and $72^{\circ} \mathrm{C}$ for $2.5 \mathrm{~min}$, with a final extension of $72^{\circ} \mathrm{C}$ for $10 \mathrm{~min}$. Electrophoresis of PCR products was run in a $2 \%$ agarose gel with a $100 \mathrm{bp}$ DNA ladder. Bands were visualized using $0.1 \%$ ethidium bromide stain on a UV documentation system (MiniBis Pro ${ }^{\circledR}$ ). In all cases, ultra-pure water and gill tissue of Oreochromis niloticus were used as negative controls, whereas DNA from the parasites was used as a positive control.

All PCR analyses were done in triplicate, and positive fragments were forward- and reversesequenced at the CINVESTAV IPN-Unidad Irapuato. Sequences were aligned manually, and BLASTn searches were performed against public databases in GenBank for preliminary matching and comparison with original sequences from the 28S rRNA-based identification of monogeneans of the genus Cichlidogyrus (http://www.ncbi.nlm.nih.gov/blast/Blast). 


\section{RESULTS}

\section{PCR with Cichlidogyrus spp. genomic DNA}

We were not able to identify, to species level, all of the Cichlidogyrus spp. isolated in this study. We evaluated only their main morphological characteristics, but in a qualitative way we were able to assess that Cichlidogyrus sclerosus occurred more frequently than other species of this genus in Oreochromis niloticus-followed by Cichlidogyrus tilapiae, $C$. haplochromii and C. longicornis (Jiménez-García et al. 2001).

DNA from single individuals was used for the PCR standardization to increase the sensitivity of the test for its subsequent use with mucus from Nile tilapia. All PCR assays were highly sensitive with the 5 sets of primers used individually. We observed amplicons of size 188 bp with primer set Cicly 1, 180 bp with primer set Cicly 2, 150 bp with primer set Cicly 3, 159 bp with primer set Cicly 4, and 189 bp with primer set Cicly 5 (Fig. 1A). We also observed some variability after titrating the primers. The lower detection limit was 4 pM for Cicly 1, 30 pM for Cicly 2, 2 pM for Cicly 3, 2 pM for Cicly 4, and 4 pM for Cicly 5. To avoid this variability, we decided to use each set of primers at $30 \mathrm{pM}$ in subsequent analyses. We used these conditions to titrate DNA isolated from each parasite, and the lower detection limit was $0.03 \mathrm{ng}$ for Cicly 1, $1 \mathrm{ng}$ for Cicly 2, $0.006 \mathrm{ng}$ for Cicly 3, $0.007 \mathrm{ng}$ for Cicly 4, and $0.12 \mathrm{ng}$ for Cicly 5 .

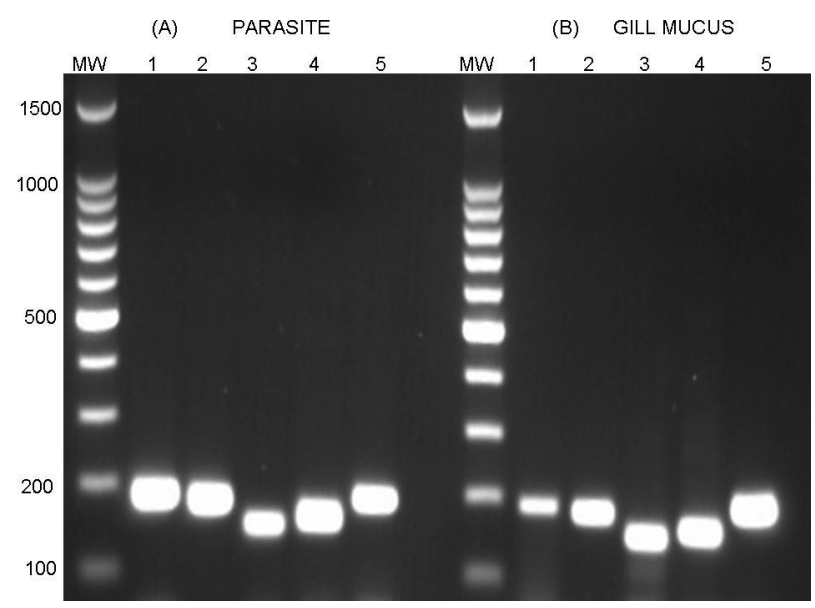

Fig. 1. PCR assays for detection of Cichlidogyrus spp. genomic DNA from (A) parasite tissue and (B) gill mucus from infected Nile tilapia Oreochromis niloticus. Lane MW: 100 bp DNA ladder; Lane 1: Cicly 1, amplicon size $=188 \mathrm{bp}$; Lane 2: Cicly 2, amplicon size $=180 \mathrm{bp}$; Lane 3 : Cicly 3, amplicon size $=150$ bp; Lane 4: Cicly 4, amplicon size = 159 bp; Lane 5: Cicly 5, amplicon size $=189 \mathrm{bp}$
We also tested the specificity of the Cichlidogyrus spp. PCR assays against DNA from Gyrodactylus cichlidarum, Trichodina spp. and Enterogyrus spp. None of these parasite tissues amplified in specific regions for the primer sets Cicly 1 to 5 .

\section{PCR on Cichlidogyrus spp. DNA in mucus from Nile tilapia}

No fish died as a result of handling stress during the collection of mucus. The PCR on mucus from the 23 infected Nile tilapia amplified DNA fragments of the same size as for the Cichlidogyrus spp. PCR assays (Fig. 1B). In this case, we corroborated the PCR-positive reaction with the presence of monogeneans by microscopy. The number of parasites isolated ranged from 1 to 162 per fish.

We did not observe amplification of DNA from the mucus of the 45 parasite-free Oreochromis niloticus. In all cases, $100 \%$ sensitivity and specificity was observed.

\section{Sequence matching of PCR products using Cichlidogyrus spp. DNA}

Sequences of the PCR products obtained with the 5 sets of primers were submitted to GenBank to check against the genome of Cichlidogyrus sclerosus (D1 to D2 region of the LSU 28S rDNA gene from which the primers were designed). The PCR products obtained with all 5 sets of primers had 95 to $100 \%$ homology with the corresponding region (DQ157660.1 GenBank) (Wu et al. 2006). The amplicons also matched the LSU rDNA region of C. cubitus (HQ010037.1), C. falcifer (HQ010024.1), C. tilapiae (HQ010029.1), C. arthracanthus (HQ010022.1), C. ergensi (HQ010038.1), C. pouyaudi (HQ010039.1), C. digitatus (HQ010023.1), C. longicirrus (HQ010026.1) C. acerbus (HQ010036.1), Cichlidogyrus sp. 2 AS-2010 (HQ010028.1), Cichlidogyrus sp. 1 AS-2010 (HQ010027.1), C. aegypticus (HQ010021.1), and C. halli (HQ010025.1) (Mendlová et al. 2010), and also some regions of the D1 to D2 domain of LSU rDNA and the combined LSU and partial sequence of small subunit (SSU) rDNA data sets of $\mathrm{Ci}$ chlidogyrus sp. 1 XW-2006 (DQ537367.1) and Cichlidogyrus sp. 2 XW-2006 (DQ537368.1) (Wu et al. 2007).

A small region (25\% of total coverage) showed $>90 \%$ homology with the D1 to D2 regions of LSU rDNA from Scutogyrus longicornis (DQ157659.1) (Wu et al. 2006) and the LSU rDNA region of $S$. longicornis (HQ010035.1) (Mendlová et al. 2010). The 
amplicons also matched the partial C1, full D1 and partial C2 domains of 28S rDNA from Cichlidogyrus sp. MLJ1 (AF218124.1) (Mollaret et al. 2000) (Table 2). Additionally, Cicly 2 recognized a small region ( $12 \%$ of coverage; $89 \%$ of homology) with the partial 28S rDNA of a species of Dactylogyridae, 1 YS-2008 (EU836211.1), and Haliotrema sp. 1 TY2005 (DQ058213.1) (Tingbao et al. 2006).

\section{Sequence matching of PCR products using DNA from gill mucus}

As with DNA from the parasite, the amplified products using DNA from mucus were also compared and aligned first with the original sequence of Cichlidogyrus sclerosus. The 5 primer sets amplified sequences which had $~ 91$ to $98 \%$ homology with the original region D1 to D2 of LSU rDNA (28S gene) (DQ157660.1) GenBank (Wu et al. 2006). The amplified sequences also matched the same set of parasites previously described: the LSU rDNA region of C. cubitus (HQ010037.1), C. falcifer (HQ010024.1), C. tilapiae (HQ010029.1), C. arthracanthus (HQ010022.1), C. ergensi (HQ010038.1), C. pouyaudi (HQ010039.1), C. digitatus (HQ010023.1), C. longicirrus (HQ010026.1), C. acerbus (HQ010036.1), Cichlidogyrus sp. 2 AS-2010 (HQ010028.1), Cichlidogyrus sp. 1 AS-2010 (HQ010027.1), C. aegypticus (HQ010021.1) and $C$. halli (HQ010025.1) (Mendlová et al. 2010). The amplicons also matched regions of the D1 to D2 domain of LSU rDNA and the combined LSU and partial sequence of small subunit (SSU) rDNA data sets of Cichlidogyrus sp. 1 XW-2006 (DQ537367.1) and Cichlidogyrus sp. 2 XW-2006 (DQ537368.1) (Wu et al. 2007).

A small region ( $8 \%$ of total coverage; $>90 \%$ of homology) matched the D1 to D2 regions of LSU rDNA from Scutogyrus longicornis (DQ157659.1) (Wu et al. 2006) and (HQ010035.1) (Mendlová et al. 2010). The amplicons also matched the partial C1, full D1 and partial C2 domains of 28S rDNA of Cichlidogyrus sp. MLJ1 (AF218124.1) (Mollaret et al. 2000) (Table 3). Only sequences amplified by Cicly 4 and Cicly 5 had $86 \%$ homology with C. pouyaudi (DQ157655.1) (Wu et al. 2006).

Additionally, Cicly 2 recognized a small region ( $8 \%$ of coverage; $88 \%$ of homology) with the partial 28S rDNA of a species of Dactylogyridae, 1 YS-2008 (EU836211.1) and Haliotrema sp. 1 TY-2005 (DQ058213.1) (Tingbao et al. 2006).

Table 2. Percentage (\%) similarity of the PCR products obtained by using primers Cicly 1 to Cicly 5 (see Table 1), with DNA from Cichlidogyrus sclerosus tissue, to various partial sequences of the 28S rDNA of monogeneans described in GenBank.

Bold: incomplete coverage $(96 \%)$; italic: minimal coverage $(15 \%)$; -: no matching

\begin{tabular}{|c|c|c|c|c|c|c|c|}
\hline \multirow[t]{2}{*}{ Accession number } & \multirow{2}{*}{$\begin{array}{l}\text { Parasite } \\
\text { (partial sequence of } 28 \mathrm{~S} \text { rDNA) }\end{array}$} & \multicolumn{5}{|c|}{ \%Similarity (Cicly primer set) } & \multirow[t]{2}{*}{ Source } \\
\hline & & 1 & 2 & 3 & 4 & 5 & \\
\hline DQ157660.1 & C. sclerosus & 99 & 100 & 100 & 100 & 95 & Wu et al. $(2006)^{\mathrm{a}}$ \\
\hline HQ010037.1 & C. cubitus & 97 & 96 & 98 & 90 & 95 & Mendlová et al. $(2010)^{\mathrm{b}}$ \\
\hline HQ010024.1 & C. falcifer & 97 & 95 & 97 & 90 & 95 & Mendlová et al. (2010) \\
\hline HQ010029.1 & C. tilapiae & 97 & 96 & 97 & 89 & 96 & Mendlová et al. (2010) \\
\hline HQ010036.1 & C. acerbus & 96 & 96 & 97 & 90 & 95 & Mendlová et al. (2010) \\
\hline HQ010028.1 & Cichlidogyrus sp. 2 AS-2010 & 96 & 96 & 97 & 90 & 95 & Mendlová et al. (2010) \\
\hline HQ010027.1 & Cichlidogyrus sp. 1 AS-2010 & 96 & 97 & 96 & 91 & 94 & Mendlová et al. (2010) \\
\hline HQ010021.1 & C. aegypticus & 95 & 95 & 98 & 90 & 94 & Mendlová et al. (2010) \\
\hline HQ010025.1 & C. halli & 94 & 96 & 98 & 90 & 93 & Mendlová et al. (2010) \\
\hline HQ010022.1 & C. arthracanthus & 95 & 95 & 96 & 90 & 94 & Mendlová et al. (2010) \\
\hline HQ010035.1 & Scutogyrus longicornis & 95 & 94 & 95 & 89 & 92 & Mendlová et al. (2010) \\
\hline DQ157659.1 & S. longicornis & 95 & 94 & 95 & 89 & 92 & Wu et al. (2006) \\
\hline HQ010038.1 & C. ergensi & 95 & 95 & 98 & 89 & 94 & Mendlová et al. (2010) \\
\hline HQ010039.1 & C. pouyaudi & 88 & 94 & 97 & 86 & 86 & Mendlová et al. (2010) \\
\hline HQ010023.1 & C. digitatus & 97 & 95 & 96 & 88 & 95 & Mendlová et al. (2010) \\
\hline HQ010026.1 & C. longicirrus & 96 & 96 & 96 & 87 & 94 & Mendlová et al. (2010) \\
\hline DQ537367.1 & Cichlidogyrus sp. 1 XW-2006 & 96 & 93 & 97 & - & 95 & Wu et al. (2007) \\
\hline DQ537368.1 & Cichlidogyrus sp. 2 XW-2006 & 97 & 96 & 97 & 89 & 96 & Wu et al. $(2007)^{\mathrm{c}}$ \\
\hline AF218124.1 & Cichlidogyrus sp. MLJ1 & 95 & - & 96 & - & 94 & Mollaret et al. $(2000)^{\mathrm{d}}$ \\
\hline \multicolumn{8}{|c|}{ apartial C1, full D1 and partial C2 domains of 28S rDNA data } \\
\hline \multicolumn{8}{|c|}{${ }^{b}$ LSU rDNA data } \\
\hline \multicolumn{8}{|c|}{${ }^{\mathrm{C} D} 1$ to D2 domain of LSU rDNA and the combined LSU and partial sequence of SSU rDNA data sets } \\
\hline
\end{tabular}


Table 3. Percentage (\%) similarity of the PCR products obtained by using primers Cicly 1 to Cicly 5 (see Table 1), with DNA from mucus of Nile tilapia gills, to various partial sequences of the $28 \mathrm{~S}$ rDNA of monogeneans described in GenBank. Bold: incomplete coverage $(96 \%)$; italic: limited coverage $(8 \%) ;-$ : no matching

\begin{tabular}{|c|c|c|c|c|c|c|c|}
\hline \multirow[t]{2}{*}{ Accession number } & \multirow{2}{*}{$\begin{array}{l}\text { Parasite } \\
\text { (partial sequence of } 28 \mathrm{~S} \text { rDNA) }\end{array}$} & \multicolumn{5}{|c|}{ \%Similarity (Cicly primer set) } & \multirow[t]{2}{*}{ Source } \\
\hline & & 1 & 2 & 3 & 4 & 5 & \\
\hline DQ157660.1 & C. sclerosus & 96 & 95 & 97 & 91 & 98 & Wu et al. $(2006)^{a}$ \\
\hline HQ010037.1 & C. cubitus & 96 & 98 & 96 & 95 & 98 & Mendlová et al. $(2010)^{\mathrm{b}}$ \\
\hline HQ010029.1 & C. tilapiae & 97 & 97 & 97 & 98 & 99 & Mendlová et al. (2010) \\
\hline HQ010024.1 & C. falcifer & 96 & 98 & 98 & 91 & 97 & Mendlová et al. (2010) \\
\hline DQ537368.1 & Cichlidogyrus sp. 2 XW-2006 & 97 & 97 & 97 & 98 & 99 & Wu et al. $(2007)^{\mathrm{c}}$ \\
\hline HQ010023.1 & C. digitatus & 96 & 97 & 98 & 96 & 98 & Mendlová et al. (2010) \\
\hline HQ010036.1 & C. acerbus & 96 & 98 & 98 & 96 & 97 & Mendlová et al. (2010) \\
\hline HQ010028.1 & Cichlidogyrus sp. 2 AS-2010 & 96 & 98 & 98 & 96 & 97 & Mendlová et al. (2010) \\
\hline HQ010026.1 & C. longicirrus & 96 & 97 & 98 & 89 & 97 & Mendlová et al. (2010) \\
\hline DQ537367.1 & Cichlidogyrus sp. 1 XW-2006 & 96 & 97 & 98 & 94 & 97 & Wu et al. (2007) \\
\hline HQ010027.1 & Cichlidogyrus sp. 1 AS-2010 & 95 & 96 & 97 & 92 & 97 & Mendlová et al. (2010) \\
\hline HQ010021.1 & C. aegypticus & 95 & 98 & 97 & 93 & 96 & Mendlová et al. (2010) \\
\hline HQ010025.1 & Cichlidogyrus halli & 95 & 97 & 97 & 92 & 96 & Mendlová et al. (2010) \\
\hline HQ010022.1 & C. arthracanthus & 95 & 98 & 95 & 93 & 95 & Mendlová et al. (2010) \\
\hline HQ010038.1 & C. ergensi & 96 & 98 & 98 & 93 & 96 & Mendlová et al. (2010) \\
\hline HQ010035.1 & Scutogyrus longicornis & 95 & 95 & 96 & 92 & 96 & Mendlová et al. (2010) \\
\hline DQ157659.1 & S. longicornis & 95 & 95 & 96 & 92 & 96 & Wu et al. (2006) \\
\hline HQ010039.1 & C. pouyaudi & - & 96 & 94 & 93 & 87 & Mendlová et al. (2010) \\
\hline AF218124.1 & Cichlidogyrus sp. MLJ1 & 95 & - & 96 & - & 97 & Mollaret et al. $(2000)^{\mathrm{d}}$ \\
\hline DQ157660.1 & C. sclerosus & 96 & 95 & 97 & 91 & 98 & Wu et al. $(2006)^{\mathrm{a}}$ \\
\hline HQ010037.1 & C. cubitus & 96 & 98 & 96 & 95 & 98 & Mendlová et al. $(2010)^{\mathrm{b}}$ \\
\hline HQ010029.1 & C. tilapiae & 97 & 97 & 97 & 98 & 99 & Mendlová et al. (2010) \\
\hline HQ010024.1 & C. falcifer & 96 & 98 & 98 & 91 & 97 & Mendlová et al. (2010) \\
\hline DQ537368.1 & Cichlidogyrus sp. 2 XW-2006 & 97 & 97 & 97 & 98 & 99 & Wu et al. $(2007)^{\mathrm{c}}$ \\
\hline HQ010023.1 & C. digitatus & 96 & 97 & 98 & 96 & 98 & Mendlová et al. (2010) \\
\hline HQ010036.1 & C. acerbus & 96 & 98 & 98 & 96 & 97 & Mendlová et al. (2010) \\
\hline HQ010028.1 & Cichlidogyrus sp. 2 AS-2010 & 96 & 98 & 98 & 96 & 97 & Mendlová et al. (2010) \\
\hline HQ010026.1 & C. longicirrus & 96 & 97 & 98 & 89 & 97 & Mendlová et al. (2010) \\
\hline DQ537367.1 & Cichlidogyrus sp. 1 XW-2006 & 96 & 97 & 98 & 94 & 97 & Wu et al. (2007) \\
\hline HQ010027.1 & Cichlidogyrus sp. 1 AS-2010 & 95 & 96 & 97 & 92 & 97 & Mendlová et al. (2010) \\
\hline HQ010021.1 & C. aegypticus & 95 & 98 & 97 & 93 & 96 & Mendlová et al. (2010) \\
\hline HQ010025.1 & Cichlidogyrus halli & 95 & 97 & 97 & 92 & 96 & Mendlová et al. (2010) \\
\hline HQ010022.1 & C. arthracanthus & 95 & 98 & 95 & 93 & 95 & Mendlová et al. (2010) \\
\hline HQ010038.1 & C. ergensi & 96 & 98 & 98 & 93 & 96 & Mendlová et al. (2010) \\
\hline HQ010035.1 & Scutogyrus longicornis & 95 & 95 & 96 & 92 & 96 & Mendlová et al. (2010) \\
\hline DQ157659.1 & S. longicornis & 95 & 95 & 96 & 92 & 96 & Wu et al. (2006) \\
\hline HQ010039.1 & C. pouyaudi & - & 96 & 94 & 93 & 87 & Mendlová et al. (2010) \\
\hline AF218124.1 & Cichlidogyrus sp. MLJ1 & 95 & - & 96 & - & 97 & Mollaret et al. $(2000)^{\mathrm{d}}$ \\
\hline
\end{tabular}

\section{DISCUSSION}

For many years the presence of monogeneans, such as Cichlidogyrus spp., has been a recurrent problem for Nile tilapia farms. Control of cichlidogyriasis is based on chemical substances that are inefficient and which could have potential toxicity and/or involve additional costs. Current methods for detecting this parasite require lethal sampling of fish, which increases costs in local farms. In this study, we have standardized PCR-based testing that can detect DNA isolated directly from Cichlidogyrus spp. as well as the parasite's DNA in mucus from Nile tilapia Oreochromis niloticus.

The PCR standardization reported herein has several advantages. The 5 pairs of primers were able to amplify their target sequences under the same PCR conditions (Coleman \& Tsongalis 2006). All the PCRpositive results from gill mucus were confirmed by the presence of the parasite at necropsy. One of the 
major findings is that the PCR carried out on gill mucus is able to detect a single parasite; this is an advantage because, with this test, we can detect low levels of parasites (i.e. early infection) without killing the fishes.

All the isolated parasites resembled Cichlidogyrus spp. in that they had sclerotized structures in the attachment organ (the haptor) and characteristic morphology of the reproductive organs (Mollaret et al. 2000). In a previous study, 5 species of Cichlidogyrus (C. tilapiae, C. sclerosus, C. dossui, C. haplochromii and C. longicornis) were reported from Oreochromis aureus and O. niloticus (Jiménez-García et al. 2001). We used Nile tilapia from the same facilities; we found that C. sclerosus was more prevalent, but we also found fewer of the other 4 species described previously. Thus, we decided to standardize the PCR tests at 'genus' level to avoid any misleading information. All PCR standardizations were performed using DNA from single individuals, and no false-positive and/or false-negative results were found. This PCR approach, which uses a highly conserved gene, has another advantage: it could be used in Nile tilapia farms around the world because, in both natural and culture conditions, several species of Cichlidogyrus are always present. Some of these species are morphologically highly variable, so it can be difficult to distinguish species on a morphological basis (Pouyad et al. 2006, Boungou et al. 2008, Mendlová et al. 2010); but what is important is that all of these species can give rise to cichlidogyriasis, and hence are potential causes of economic loss.

During the process of primer standardization, we observed some variability in primer sensitivity, ranging from $2 \mathrm{pM}$ to $30 \mathrm{pM}$. The minimum concentration of DNA detected ranged from $0.007 \mathrm{ng}$ to $0.12 \mathrm{ng}$ of DNA. During the alignment analyses of products obtained by amplification of DNA from the parasite we found $\sim 100 \%$ homology between the PCR products of all 5 pairs of primers and DNA from the original sequence of Cichlidogyrus sclerosus (Wu et al. 2006). Likewise, the sequences in the DNA amplified from mucus were specific to the original sequence of the genus Cichlidogyrus (DQ537367.1) (Wu et al. 2007). Alignment and matching were similar to those found in previous studies with sequences from the parasite (93 to 99\%) (Mollaret et al. 2000, Wu et al. 2006, 2007).

Special caution has to be taken with the primer pair Cicly 2, as a small region of the amplified sequence matches the original sequences of Haliotrema sp. and Scutogyrus longicornis. In this case, it is necessary to validate the PCR tests with DNA of these monogeneans to assess the primers' specificity because, after all, in this study, we are reporting only matches from a very conserved gene. According to some molecular phylogenetic studies, S. longicornis could be included within the genus Cichlidogyrus, suggesting the non-monophyly of Cichlidogyrus (Pouyad et al. 2006, Wu et al. 2007, Mendlová et al. 2010).

In conclusion, we report the first use of a specific sequence from the 28S rDNA gene of Cichlidogyrus spp. for molecular diagnosis. Our PCR assays detected DNA obtained directly from the parasite and also the parasite's DNA present in the gill mucus of Nile tilapia, so that this approach could indicate a putative infestation. This presumptive test could be used in conjunction with parasitological and/or serological tests for early detection of the presence of the parasite in order to avoid the possibility of epizootic outbreaks of cichlidogyriasis in culture systems. The detection of DNA from gill mucus of Nile tilapia is a novel approach which is not invasive to the host, so this approach might facilitate the use of testing in order to help avoid economic losses on Nile tilapia farms.

As parasites feed on gill mucus and debris, it is possible that the PCR test is detecting DNA from excretory/secretory products of the parasite. This is a hypothesis that we are currently evaluating, as the PCR can detect DNA from a single egg (data not shown). In further studies it will be necessary to include a panel of DNA from Scutogyrus sp. and Haliotrema sp. to evaluate the specificity of the PCR assays.

Acknowledgements. Special thanks to Mr. G. Hernández Cisneros for helping with the standardization of the PCR assays. This project was funded by external services of the laboratory of Immunology and Molecular Biology at CINVESTAV IPN Unidad Mérida.

\section{LITERATURE CITED}

Boungou M, Kabre GB, Markes A, Sawadogo L (2008) Dynamics of population of five parasitic monogeneans of Oreochromis niloticus Linné, 1757 in the Dam of Loumbila and possible interest in intensive pisciculture. Pakistan J Biol Sci 11:1317-1323

Buchmann K, Lindenstrom T (2002) Interactions between monogenean parasites and their fish hosts. Int J Parasitol 32:309-319

Coleman WB, Tsongalis GJ (2006) The polymerase chain reaction. In: Coleman WB, Tsongalis GJ (eds) Molecular diagnostics for the clinical laboratorian, 2nd edn. Humana Press, Totowa, NJ, p 47-56

El-Sayed MA (2006) Tilapia culture. CABI Publishing, Wallingford, p 139-159 
Fitzsimmons K, Carvalho J (eds) (2000) Tilapia aquaculture in the 21st century: Proceedings of the Fifth International Symposium on Tilapia in Aquaculture, Rio de Janeiro. Departmento de Pesca e Aqüicultura, Ministério de Agricultura, Brasilia

Galen RS, Gambino SR (1995) Beyond normality: the predictive value and efficiency of medical diagnoses. John Wiley, New York, NY, p 10-14

Gonçalves ELT, Jerônimo GT, Martins ML (2009) On the importance of monogenean helminthes in Brazilian cultured Nile tilapia. Neotrop Helminthol 3:53-56

> Jiménez-García MI, Vidal-Martínez VM, López-Jiménez S (2001) Monogeneans in introduced and native cichlids in Mexico: evidence for transfer. J Parasitol 87:907-909

Kabata Z (1985) Parasites and diseases of fish cultured in the tropics. Taylor \& Francis, London

Khalil LF (1971) Checklist of the helminth parasites of African freshwater fishes. Tech Comm No. 42, Commonwealth Agricultural Bureaux, St. Albans

Lindstrom NM, Call DR, House ML, Moffitt CM, Cain KD (2009) A quantitative enzyme-linked immunosorbent assay and filtration-based fluorescent antibody test as potential tools to screen broodstock for infection with Flavobacterium psychrophilum. J Aquat Anim Health 21:43-56

López-Vázquez C, Dopazo CP, Olveira JG, Barja JL, Bandín I (2006) Development of a rapid, sensitive and non-lethal diagnostic assay for the detection of viral haemorrhagic septicaemia virus. J Virol Methods 133:167-174

Mendlová M, Pariselle A, Vyskočilová M, Šimková A (2010) Molecular phylogeny of monogeneans parasitizing African freshwater Cichlidae inferred from LSU rDNA sequences. Parasitol Res 107:1405-1413

Miriam A, Griffiths SG, Lovely JE, Lynch WH (1997) PCR and probe-PCR assays to monitor broodstock Atlantic salmon (Salmo salar L.) ovarian fluid and kidney tissue for presence of DNA of the fish pathogen Renibacterium salmoninarum. J Clin Microbiol 35:1322-1326

Mollaret I, Lim LHS, Justine JL (2000) Phylogenetic position of the monogeneans Sundanonchus, Thaparocleidus, and Cichlidogyrus inferred from 28S rDNA sequences. Int J Parasitol 30:659-662

Paperna I (1968) Ectoparasitic infections of fish of Volta lake, Ghana. Bull Wildl Dis Assoc 4:135-137

Editorial responsibility: Dieter Steinhagen,

Hannover, Germany
Paperna I, Thurston JP (1968) Report on ectoparasitic infections of freshwater fish in Africa. Bull Off Int Epizoot 69: 1192-1206

> Pouyad L, Desmarais E, Deveney M, Pariselle A (2006) Phylogenetic relationship among monogenean gill parasites (Dactylogiridae, Ancyrocephalidae) infesting tilapiine hosts (Cichlidae): systematic and evolutionary implications. Mol Phylogen Evol 38:241-249

Rozen S, Skaletsky HJ (2000) Primer3 on the WWW for general users and for biologist programmers. In: Krawetz S, Misener S (eds) Bioinformatics methods and protocols: methods in molecular biology. Humana Press, Totowa, NJ, p 365-386

- Sanders JL, Kent ML (2011) Development of a sensitive assay for the detection of Pseudoloma neurophilia in laboratory populations of the zebra fish Danio rerio. Dis Aquat Org 96:145-156

> Sandoval-Gío JJ, Rodríguez-Canul R, Vidal-Martínez VM (2008) Humoral antibody response of the tilapia Oreochromis niloticus against Cichlidogyrus spp. J Parasitol 94:404-409

> Smith SA, Levy MG, Noga EJ (1992) Development of an enzyme-linked inmunosorbent assay (ELISA) for the detection of antibody to the parasitic dinoflagellate Amyloodinium ocellatum in Oreochromis aureus. Vet Parasitol 42:145-155

> Tingbao Y, Kritsky DC, Yuan S, Jianying Z, Suhua S, Agrawal N (2006) Diplectanids infesting the gills of the barramundi Lates calcarifer (Bloch) (Perciformes: Centropomidae), with the proposal of Laticola n. g. (Monogenoidea: Diplectanidae). Syst Parasitol 63:127-141

> Wu XY, Zhu XQ, Xie MQ, Li AX (2006) The radiation of Haliotrema (Monogenea: Dactylogyridae: Ancyrocephalinae): molecular evidence and explanation inferred from LSU rDNA sequences. Scutogyrus longicornis 28S ribosomal RNA gene, partial sequence. Parasitol 132: $659-668$

Wu XY, Zhu XQ, Xie MQ, Li AX (2007) The evaluation for generic-level monophyly of Ancyrocephalinae (Monogenea, Dactylogyridae) using ribosomal DNA sequence data. Cichlidogyrus sp. 1 XW-2006 28S ribosomal RNA gene, partial sequence. Mol Phylogenet Evol 44: $530-544$

Submitted: May 23, 2011; Accepted: December 15, 2011 Proofs received from author(s): March 9, 2012 